\title{
INFLUENCE OF LOCAL ADMINISTRATION OF SEROTONIN ON MITOCHONDRIAL ENZYMF ACTIVITY OF RAT SKELETAL MUSCLE
}

\author{
Yuichiro ARAI and Yoshio AIZAWA \\ Department of Pharmacology, Tokyo College of Pharmacy, \\ Horinonchi, Hachioji 192-03. Japan \\ Accepted December 18, 1975
}

Influence of local administration of serotonin on mitochondrial enzyme activities of rat skeletal muscle was studied. We previously observed that local administration of dextran into the rat skeletal muscle provoked an evident increase in succinic dehydrogenase (SDH) activity in the injected muscle (1). Serotonin has been used as a phlogistic as well as dextran and carrageenin in this species $(2,3)$. The present experiment was performed to determine whether or not an intramuscular administration of serotonin also increases such a change in SDH activity in the affected muscle.

Two hundred $/ \mu \mathrm{g}$ of serotonin (Wako Pure Chemicals Co. Ltd) in $0.1 \mathrm{ml}$ of saline solution $(\mathrm{pH} 7)$ was injected into the left gastrocnemius muscle of Wistar strain albino male rats weighing about $200 \mathrm{~g}$. The same amount of saline solution was injected into the right muscle as control. The muscles were removed $6 \mathrm{hr}$ after injection and homogenized with $0.1 \mathrm{M}$ Tris- $\mathrm{HCl}$ buffer containing $0.25 \mathrm{M}$ sucrose $(\mathrm{pH} 7.4)$, after which the homogenates were centrifuged at $600 \times \mathrm{g}$ for $10 \mathrm{~min}\left(0^{\circ} \mathrm{C}\right)$. A part of the supernatant $(600 \times \mathrm{g}$ sup) was further centrifuged at $12,000 \times \mathrm{g}$ for $15 \mathrm{~min}(0 \mathrm{C})$, and the precipitate was suspended in the buffer. Six hundred $\times \mathrm{g}$ sup, the suspension of the precipitate at $12,000 \times \mathrm{g}(12,000 \times \mathrm{g} p \mathrm{pt})$, and the supernatant at $12,000 \times \mathrm{g}(12,000 \% \mathrm{~g}$ sup) were used as enzyme sources. Activities of SDH (4), malic dehydrogenase (MDH) (5), ascorbate oxidase ( $\mathrm{AO}$ ) (6), and lactic dchydrogenase (LDH) (5) were measured by the oxygen electrode method. ATPase activity was measured by the method of Tanaka and Strickland (7), and hexokinase activity was measured by the method of Darrow and Colowick (8). These enzyme activities were determined in the hypotonic medium according to the original report (4-8) and the isotonic medium adjusted with sucrose.

Increase in muscle weight reached a maximum $6 \mathrm{hr}$ after serotonin injection, value being about $116 \%$ that of the control. SDH activity in 600 'g sup measured in isotonic medium was markedly increased by serotonin injection. The value was about $328 \%$ of the control as shown in Table 1 . But, when SDH activity in $600 \times \mathrm{g}$ sup was measured in hypotonic medium, the enzyme activity was not changed by serotonin. SDH activity in $12,000 \times \mathrm{g}$ ppt was not changed by serotonin when the activity was measured in isotonic and hypotonic medium. SDH activity in $12,000 \times \mathrm{g}$ sup was significantly increased. On the 
TABLE 1. Influence of Incal administration of serotonin on succinic dehydrogenase activity in rat skeletal muscle

\begin{tabular}{|c|c|c|c|c|c|}
\hline & \multicolumn{2}{|c|}{$600 \times \mathrm{g}$ sup } & \multicolumn{2}{|c|}{$12,000 \times \mathrm{g} \mathrm{ppt}$} & \multirow{2}{*}{$\begin{array}{c}12,000 \times \text { g sup } \\
\text { Isotonic } \\
(10)\end{array}$} \\
\hline & $\begin{array}{c}\text { Isotonic } \\
(6)\end{array}$ & $\begin{array}{c}\text { Hypotonic } \\
\text { (4) }\end{array}$ & $\begin{array}{c}\text { Isotonic } \\
\text { (4) }\end{array}$ & $\begin{array}{c}\text { Hypotonic } \\
(6)\end{array}$ & \\
\hline Control & $1.14: 0.24$ & $2.03 \quad 0.46$ & $12.30+3.81$ & $13.18-1.41$ & $0.97-0.11$ \\
\hline $\begin{array}{r}\text { Serotonin } \\
\text { injected }\end{array}$ & $3.74 \perp 1.20^{*}$ & $2.21 \div 0.55$ & $12.60+4.21$ & $12.43 \pm 3.05$ & $1.18 \pm 0.01^{* *}$ \\
\hline$\%$ of Control & 327.6 & 108.9 & 102.4 & 94.3 & 122.0 \\
\hline
\end{tabular}

Value was expressed as nmole $\mathrm{O}_{2} / \mathrm{mg}$ prolein $/ \mathrm{min}$.

Number of experiments is indicated in parentheses.

*: $P<0.05, * *: P<0.01$, Significantly different from control.

TABLE 2. Influence of local administration of serotonin on enzyme activities in rat skeletal muscle

\begin{tabular}{|c|c|c|c|c|}
\hline & & Control & Serotonin injected & $\%$ of Control \\
\hline \multicolumn{5}{|l|}{$\begin{array}{l}600 \times \text { g sup } \\
\text { Isotonic }\end{array}$} \\
\hline ATPase & (5) & 0.26 .20 .01 & $0.28 \ldots 0.01$ & 107.8 \\
\hline $\mathrm{MDH}$ & (6) & $25.80+2.81$ & $24.08=1.46$ & 93.3 \\
\hline $\mathrm{AO}$ & (6) & $3.44: 0.66$ & $3.27 \div 0.30$ & 94.9 \\
\hline $\mathrm{LDH}$ & (6) & $28.39 \div 3.02$ & $32.29-3.60$ & 113.7 \\
\hline Hexokinase & (5) & $0.023 \div 0.002$ & $0.024 \doteq 0.002$ & 103.4 \\
\hline \multicolumn{5}{|l|}{ Hypotonic } \\
\hline ATPase & (5) & $0.38:-0.08$ & $0.48-0.03$ & 127.4 \\
\hline $\mathrm{MDH}$ & (4) & $29.98 \div 4.34$ & $31.62=5.19$ & 105.5 \\
\hline $\mathrm{AO}$ & (4) & $4.35-0.75$ & $4.63 \div 0.80$ & 106.6 \\
\hline LDH & (4) & $44.44=4.43$ & $44.06 \div 4.06$ & 99.1 \\
\hline Hexokinase & (5) & $0.025-0.001$ & $0.027+0.001$ & 109.2 \\
\hline \multicolumn{5}{|l|}{$12,000 \times \mathrm{g} \mathrm{ppt}$} \\
\hline ATPase & (5) & 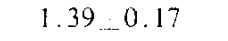 & $1.02 \perp 0.25$ & 73.5 \\
\hline $\mathrm{MDH}$ & (3) & 151.62 .35 .75 & $116.00 \div 19.98$ & 76.5 \\
\hline $\mathrm{AO}$ & (3) & $55.24 \cdot 10.79$ & $39.20-6.20$ & 71.0 \\
\hline LDH & (4) & 0 & 0 & \\
\hline Hexokinase & $(5)$ & 0 & 0 & \\
\hline \multicolumn{5}{|l|}{ Hypotonic } \\
\hline ATPase & (5) & 4.361 .13 & $3.85 \perp 0.81$ & 88.3 \\
\hline $\mathrm{MDH}$ & (3) & $184.54: 35.41$ & $172.55: 119.98$ & 93.5 \\
\hline $\mathrm{AO}$ & (3) & $46.39: 3.22$ & $40.69-3.01$ & 87.7 \\
\hline $\mathrm{LDH}$ & (4) & 0 & 0 & \\
\hline Hexokinase & (5) & 0 & 0 & \\
\hline
\end{tabular}

ATPase activily: $\mu \mathrm{gP}$ 'mg protein $\mathrm{min}$.

$\mathrm{MDH}, \mathrm{AO}$, and LDH activity: nmole $\mathrm{O}_{2} / \mathrm{mg}$ protein $\mathrm{min}$.

Hexokinase activity: O.D.ing proteinimin.

Number of experiments is indicated in parentheses.

other hand, ATPase, LDH, MDH, AO, and hexokinase activities in $600 \times \mathrm{g}$ sup and $12,000 \times \mathrm{g}$ ppt were not changed significantly by serotonin when measured in both isotonic and hypotonic medium as shown in Table 2. 
De Grandis (9) and Nagatomo and Aizawa (10) reported that SDH activity in inflamed tissues is increased. It is also known that the size of mitochondria in rat normal tissues varies (11). SDH activity in $600 \times \mathrm{g}$ sup which contains all sizes of mitochondria was markedly increased by serotonin, but the activity in $12,000 \times \mathrm{g}$ ppt was not changed. It was expected that SDH activity of unprecipitated mitochondria at $12,000 \% \mathrm{~g}$ (light mitochondria) would be changed by serotonin. But the increase of SDH activity by serotonin was not observed when it was measured in hypotonic medium which may swell and rupture mitochondria $(12,13)$. Therefore, the amount of SDH in mitochondria may be unchanged by serotonin (13-15). These results suggest that the mitochondrial membrane perneability for substrate, especially succinate, might change with local administration of serotonin. In the present experiment, it was demonstrated that intramuscular injection of serotonin increased SDH aclivity in the injected muscle just as was observed when dextran was used as the phlogistic (1). These data collectively indicate that an increase in SDH activity induced by serotonin injection is not specific for serotonin but may be related to the nature of "inflammatory response" in the rat.

\title{
REFERENCES
}

1) Arai, Y. And Aizawn, Y.: Folia pharmacol.japon. 69, 153p (1973) (in Japanese); 2) GaratTini, S., Jort, A., Bernard. D., Carrara, C., Paglialunga, S., and Serge, D.: International Symposium on Non-steroidal Ani-inflammatory Drugs, Edited by Garattin, S. M.N.G. Dukes, p. 151 Excepta Medica Foundation, Amsterdam (1965): 3) Witer, C.A.: International Symposimm on Non-steroidal Anti-inflammatory Drugs, Edited by Garattini, S. M.N.G. Dukes, p. 190 Excepta Medica Foundation Amsterdam (1965); 4) SChntider, W.C. AND Potter, V.R.: $J$. biol. Chem. 149, 217 (1943): 5) Straub, F.B.: Biochem. J. 34, 483 (1940): 6) Gieson, D.M., Davisson, E.O., BachHawt, B.K., Ray, B.R., AND VisIling, C.S., J. biol. Chem. 203, 397 (1953); 7) Tainka, R. and StricktLand, K.P.: Archs Biochem. Biophy's. 111, $583(1965)$; 8) Darrow, R.A. ANd Colowick, S.P.: Methods in Enzymology, Edited by Colowick, S.P. And KaPLan, N.O., Vol. 5, p. 226, Academic Press, New York and London (1962); 9) De Grandis, E.: Rass. Med. Sper. 16, 43 (1969); 10) NagATOMO, T. AND AI/AWA, Y.: Folia pharmacol. japon. 67, 166 (1971) (in Japanese): 11) Bahr, G.F. ANd ZeITLeR, E.: J. cell Biol. 15, 489 (1962); 12) Lehninger, A.L.: Physiol. Res. 42, 467 (1962): 13) LeHininger, A.L.: The Mitochondrion, p. 180, W.A. Benjamin Inc., New York and Amsterdam $(1964)$; 14) LeHninger, A.L.: The Mitochondrion, p. 205, W.A. Benjamin Inc., New York and Amsterdam (1964): 15) LfHninger, A.L.: The Mitochondrion, p. 234, W.A. Benjamin Inc., New York and Amsterdam (1964)

\section{DIFFERENT PATTERNS OF INHIBITION OF DOPAMINE-3-HYDROXYLASE BY CYSTEINE}

\author{
Hiroshi IZUMI, Hideko OYAMA, Makoto HAYAKARI \\ and Hikaru OZAWA \\ Pharmaceutical Instirute, Tohohu University, Aobayama, Sendai 980, Japan
}

Accepted December 18, 1975

It has previously been reported (1) that dopamine-, 3 -hydroxylase [DBH : 3,4-dihydroxyphenethylamine, ascorbate- $\mathrm{O}_{2}$ oxidoreductase (hydroxylating), EC 1.14.2.1] was inhibited 